\title{
Construction and Expression of Specificity-Improved Single-Chain Variable Fragments against the Bioactive Naphthoquinone, Plumbagin
}

\author{
Seiichi Sakamoto, ${ }^{a}$ Futoshi Taura, ${ }^{a}$ Waraporn Putalun, ${ }^{b}$ Benyakan Pongkitwitoon, ${ }^{b}$ \\ Ryota Tsuchinashi, ${ }^{c}$ Satoshi Morimoto, ${ }^{a}$ Junei Kinjo, ${ }^{c}$ Yukihiro Shoyama, ${ }^{d}$ and Hiroyuki TanakA ${ }^{*, a}$ \\ ${ }^{a}$ Department of Medicinal Plants Breeding and Pharmacognosy, Graduate School of Pharmaceutical Sciences, Kyushu \\ University; 3-1-1 Maidashi, Higashi-ku, Fukuoka 812-8582, Japan: ${ }^{b}$ Faculty of Pharmaceutical Sciences, Khon Kaen \\ University; Khon Kaen 40002, Thailand: ${ }^{c}$ Department of Pharmacognosy, Faculty of Pharmaceutical Sciences, Fukuoka \\ University; 8-19-1 Nanakuma, Jonan-ku, Fukuoka 814-0180, Japan: and ' Department of Pharmacognosy, Faculty of \\ Pharmaceutical Sciences, Nagasaki International University; 2825-7 Huis Ten Bosch, Sasebo, Nagasaki 859-3298, Japan. \\ Received November 20, 2008; accepted December 22, 2008; published online December 25, 2008
}

We constructed a single-chain variable fragment ( $\mathrm{scFv}$ ) antibody against plumbagin (PL) with improved specific binding to PL. Variable heavy- and light-chain genes were cloned directly from the cDNA of hybridoma cell line $3 \mathrm{A3}$ and assembled using the splice-overlap extension polymerase chain reaction (SOE-PCR) with specific primers including flexible peptide $\left(\mathrm{Gly}_{4} \mathrm{Ser}\right)_{3}$ linker primers. The constructed $\mathrm{scFv}$ gene was ligated into the pET28a expression vector and transformed into Escherichia coli BL21 (DE3). The denatured protein expressed as inclusion bodies in $E$. coli was solubilized, purified, and refolded by a stepwise dialysis. Intriguingly, the refolded scFv against PL displayed higher PL-binding specificity than that of its parental monoclonal antibody, MAb 3A3, which suggests the possibility of improving the function by constructing the scFv antibody. These notable properties of the recombinant antibody against PL made it possible to develop an enzyme-linked immunosorbent assay (ELISA) for reliable determination of PL.

Key words single-chain variable fragment; plumbagin; cross-reactivity; enzyme-linked immunosorbent assay; Plumbago zeylanica

The 1,4-naphthoquinone derivatives including vitamin $\mathrm{K}$, plumbagin (PL), juglone, and shikonin are well known to possess various pharmacologic properties. Owing to their wide ranging activities such as anti-tumor, ${ }^{1)}$ radical-scavenging, ${ }^{2)}$ enzyme-inhibitory, ${ }^{3)}$ immunoenhancement, ${ }^{4)}$ platelet activation-inhibition, ${ }^{5)}$ and RNase $\mathrm{H}$ activity inhibition associated with human immunodeficiency virus-1 reverse transcriptase $^{6}$ activity, 1,4-naphoquinones have attracted much attention, and numerous 1,4-napthoquinone derivatives have been found in nature or synthesized artificially. Some of them are currently used as medicines or chemical reagents. Among them, PL (5-hydroxy-2-methyl-1,4-naphthoquinone) (Fig. 1) is a naturally occurring yellow pigment mainly isolated from the genus Plumbago (Plumbaginaceae), which have especially been attracted much attention as a drug candidate. It has been shown to have various pharmacologic activities against cancer, ${ }^{7)}$ fungi, ${ }^{8)}$ malaria, ${ }^{9)}$ insects, ${ }^{10)}$ and $\mathrm{He}$ licobacter pylori. ${ }^{11)}$ In addition, PL is capable of inhibiting cell proliferation by inducing autophagic cell death. ${ }^{12)}$ Furthermore, Sandur et al. reported that PL also down-regulates
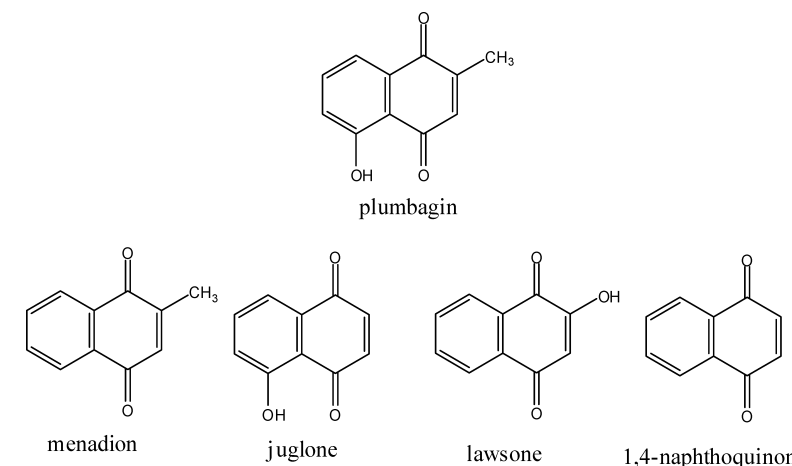

Fig. 1. Structure of Plumbagin and Related Compounds the expression of nuclear factor (NF)- $\kappa \mathrm{B}$-regulated antiapoptotic, proliferative, and angiogenic gene products, committing cells to apoptosis. ${ }^{13)}$

In our previous study, we developed an enzyme-linked immunosorbent assay (ELISA) using a monoclonal antibody against PL (MAb 3A3) and reported the specific reactivity of the assay against PL and menadione. ${ }^{14)}$ The assay shows potential as a screening method in the breeding of Plumbago zeylanica to yield high amounts of PL and the precise monitoring of PL in body fluids. In general, the usefulness of MAbs is evaluated based on their uniformity and specific binding to an antigen, which facilitates accurate immunoassays and antibody preparation. However, it is labor intensive and time consuming to obtain MAbs prepared from hybridoma cell cultures. Further, hybridoma cells can be contaminated with microorganisms. On the other hand, recent advances in recombinant DNA technology have enabled the production of single-chain variable ( $\mathrm{scFv}$ ) antibodies, which have variable regions of heavy $(\mathrm{VH})$ and light $(\mathrm{VL})$ chains with the short, flexible peptide $\left(\mathrm{Gly}_{4} \mathrm{Ser}\right)_{3}$ in bacteria. Once the gene for construction of recombinant antibodies is established, it can be kept as gene and used to construct various kinds of recombinant antibodies. Thus the scFv strategy has become one of the most common methods in antibody engineering and has been exploited in research, therapeutic, and diagnostic applications including biosensors for the detection of target molecules, ${ }^{15)}$ cytokines for immunotherapy, ${ }^{16)}$ and radioisotopes for cancer imaging. ${ }^{17)}$

In this study, we constructed a recombinant $\mathrm{scFv}$ antibody against PL (PL-scFv) derived from a monoclonal antibody against PL (MAb 3A3) for determination of PL in plant. Functional characterization of PL-scFv suggests that it has been improved to have high specific binding to PL, although the character of the $\mathrm{scFv}$ antibody is, in general, identical or 
very similar to that of the parental antibody. Subsequently, a quantitative ELISA using PL-scFv was developed and evaluated as a quality control method to monitor PL content in plants.

\section{MATERIALS AND METHODS}

Chemicals and Immunochemicals PL was purchased from Wako Pure Chemicals Industries (Osaka, Japan). Ovalbumin was purchased from Sigma-Aldrich (Steinheim, Germany). T7-Tag horseradish peroxidase (HRP) conjugate was obtained from Novagen (San Diego, CA, U.S.A.). DNA polymerase and DNA restriction enzyme were purchased from Takara (Kyoto, Japan). All other chemicals were standard commercial products of analytical reagent grade.

Preparation of PL-Ovalbumin Conjugates The synthesis of PL-ovalbumin (PL-Ova) conjugates was performed as described in our previous study ${ }^{14)}$ with some modifications. 1-Ethyl-3-(3'-dimethylaminopropyl)-carbodiimide hydrochloride (EDC; $6 \mathrm{mg}, 0.031 \mathrm{~mm}$ ) and 3'-(5-hydroxy-2methyl-1,4-naphthoquinone-3-yl) propanoic acid (3 mg, 0.012 $\mathrm{mm})$ were added to a mixture of $35 \%(\mathrm{w} / \mathrm{w})$ pyridine solution $(0.3 \mathrm{ml})$ and MES buffer consisting of $0.1 \mathrm{M} 2-(N$-morpholino) ethanesulfonic acid and $0.9 \%(\mathrm{w} / \mathrm{v})$ sodium chloride $(0.3 \mathrm{ml})$. The reaction mixture was added dropwise to MES buffer $0.3 \mathrm{ml}$ containing ovalbumin $3 \mathrm{mg}$ and then stirred at room temperature for $13 \mathrm{~h}$. Subsequently, the mixture was dialyzed against five changes of $\mathrm{H}_{2} \mathrm{O}$ for $2 \mathrm{~d}$ at $4{ }^{\circ} \mathrm{C}$ and lyophilized to yield $3.2 \mathrm{mg}$ of PL-Ova conjugate, which was used as a coating antigen in ELISA.

Plant Materials Different parts (roots, stems, and leaves) of $\mathrm{P}$. zeylanica and parts (stems and flowers) of $\mathrm{Ne}$ penthes sp. were collected from the herbal garden of Khon Kaen University, Thailand, in 2007 and identified by Dr. Waraporn Putalun, Khon Kaen University. The hairy root of $P$. zeylanica was induced by transformation with the Ri plasmid of wild type Agrobacterium rhizogenes ATCC 15834, and cultured in half-strength Murashige and Skoog medium. The plant material was cut into small pieces and dried in a hot-air oven at $50{ }^{\circ} \mathrm{C}$ for $2 \mathrm{~d}$ and then ground to powder consistency.

These samples are registered as PZ 01-04 and NS 01-04 in the herbarium of the Faculty of Pharmaceutical Sciences, Khon Kaen University.

Sample Preparation The ground powder $(50 \mathrm{mg})$ was extracted with ethyl acetate $0.5 \mathrm{ml}$ using an ultrasonic bath operated for $15 \mathrm{~min}$. The extract was then centrifuged at $2500 \mathrm{rpm}$ for $1 \mathrm{~min}$ and the supernatant was transferred to a microtube. This extraction step was repeated three times. After the final step, the extracted solution was evaporated in a water bath at $60{ }^{\circ} \mathrm{C}$ until dryness. The residue was dissolved in methanol $1 \mathrm{ml}$ and diluted appropriately for ELISA.

Construction of PL-scFv Gene DNA and RNA manipulations were performed using standard methods. ${ }^{18)}$ Total RNA $(5 \mu \mathrm{g})$ was extracted from $1 \times 10^{6}$ hybridoma cells (3A3) using the Sepasol RNA I super reagent (Nakalai Tesque, Kyoto, Japan) according to the manufacturer's instructions. First-strand cDNA was synthesized using random hexamer primers (Amersham Biosciences, Buckinghamshire, U.K.). The VH gene was amplified in the polymerase chain reaction (PCR) using established antibody-specific primers, ${ }^{19}$ ) and the PCR products were cloned into the pGEM-T vector (Promega, Madison, WI, U.S.A.), whereas the VL gene was amplified using PCR with Light Chain Mix Primer (Amersham Biosciences) and cloned into the pMD 20-T vector (Takara, Tokyo, Japan). The cloned VH and VL genes were transformed into E. coli JM109 cells. Colony PCR was used to screen positive colonies, and plasmids of positive colonies were purified and sequenced.

The VH and VL domains were assembled and linked together in the splice-overlap extension-PCR (SOE-PCR) to yield the full-length $\mathrm{scFv}$ gene. The $\mathrm{scFv}$ gene was constructed in a VH-linker-VL format with the standard 15amino acid linker $\left(\mathrm{Gly}_{4} \mathrm{Ser}\right)_{3}$ and then was subcloned downstream of the His6-tag and T7-tag of pET 28a expression vector (Novagen) to generate a $\mathrm{pET} 28 \mathrm{a} / \mathrm{scFv}$ plasmid. The $\mathrm{pET} 28 \mathrm{a} / \mathrm{scFv}$ plasmid was transformed into E. coli BL21 (DE3) cells.

The VH- and VL-specific primers for the construction of the $\mathrm{scFv}$ gene were:

$\mathrm{VH}$ for-Bam $\mathrm{HI}$,

5'-CGCGGATCCCAGGTTACTCTAAAAGAATCTGG$\mathrm{C}-3^{\prime}$;

$\mathrm{VH}$ rev-linker,

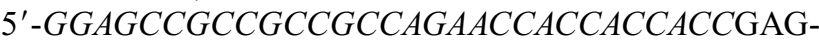
GAGACGGTGACTGA-3';

VL for-linker,

5'-GGCGGCGGCGGCTCCGGTGGTGGTGGTTCAGACATTGTGCTGACCCAG-3';

and

VL rev-SalI,

5'-AGCTTT GTCGACCTACCGTTTTATTTCCAGCTT$3^{\prime}$.

Primers VH for-BamHI, VH rev-linker, VL for-linker, and VL rev-SalI represent the forward primer for the $\mathrm{VH}$ gene with a BamHI site, reverse primer for the VH gene with the linker sequence, forward primer for the VL gene with the linker sequence, and reverse primer for the VL gene with a SalI site, respectively. In the above sequences, the restriction sites are underlined, and the italicized letters indicate linker coding sequences.

Time-Course Expression of PL-scFv Protein The time course was investigated to optimize the time for expression of the PL-scFv protein. E. coli cells were incubated in $100 \mathrm{ml}$ of Luria-Bertani (LB) broth containing $25 \mu \mathrm{g} / \mathrm{ml}$ kanamycin and cultured at $37^{\circ} \mathrm{C}$. The expression of the PL-scFv protein was induced when the optimal density at $660 \mathrm{~nm}$ reached 0.6 after the addition of $0.1 \mathrm{~mm}$ isopropyl-thio- $\beta$-D-galactopyranoside (IPTG), and the cells were harvested $(15,30,45$, $60 \mathrm{~min}$ and 2, 3, 4.5, 6, 9, $24 \mathrm{~h}$ after IPTG induction) by centrifugation, and the pellets were resuspended in lysis buffer (50 mM Tris- $\mathrm{HCl}, \mathrm{pH} 8.0$ ). Cells were ultrasonically lysed and centrifuged at $14000 \mathrm{rpm}$ for $5 \mathrm{~min}$ at $4{ }^{\circ} \mathrm{C}$. Subsequently, the pellet was resuspended in protein loading buffer [30 mM Tris- $\mathrm{HCl}, \mathrm{pH} 6.8,0.01 \%(\mathrm{w} / \mathrm{v})$ bromophenol blue, $2 \%(\mathrm{w} / \mathrm{v})$ sodium dodecyl sulfate (SDS), 10\% (v/v) glycerol, $100 \mathrm{~mm}$ dithiothreitol], heated at $96^{\circ} \mathrm{C}$ for $5 \mathrm{~min}$, and analyzed using $12.5 \%(\mathrm{w} / \mathrm{v})$ SDS-polyacrylamide gel electrophoresis (SDS-PAGE). ${ }^{20)}$

Purification of PL-scFv Protein The PL-scFv protein was purified using immobilized metal ion affinity chromatography (IMAC) which was precharged $\mathrm{Ni}^{2+}$ as an affinity 
resin. Recombinant PL-scFv antibody was solubilized in washing buffer consisting of $50 \mathrm{~mm}$ Tris- $\mathrm{HCl}$ ( $\mathrm{pH} 8.0)$ containing $6 \mathrm{M}$ guanidine $\mathrm{HCl}(\mathrm{GuHCl}), 500 \mathrm{~mm} \mathrm{NaCl}$, and $20 \mathrm{~mm}$ imidazole. After passing the sample through the column, the column was washed with a 10 -fold volume of washing buffer, and eluted with elution buffer consisting of $50 \mathrm{~mm}$ Tris- $\mathrm{HCl}(\mathrm{pH} 8.0)$ containing $6 \mathrm{M} \mathrm{GuHCl}, 500 \mathrm{~mm} \mathrm{NaCl}$, and $500 \mathrm{~mm}$ imidazole.

Refolding of PL-scFv Protein The recombinant PLscFv antibody was solubilized in $50 \mathrm{~mm}$ Tris- $\mathrm{HCl}(\mathrm{pH} \mathrm{8.0)}$ containing $6 \mathrm{M} \mathrm{GuHCl}, 200 \mathrm{~mm} \mathrm{NaCl}$, and $1 \mathrm{~mm}$ EDTA and refolded following the method of Umetsu et al. with slight modification. ${ }^{21)}$ Briefly, the solubilized $\mathrm{scFv}$ protein was reduced by the addition of $\beta$-mercaptoethanol $(\beta-\mathrm{ME})$ and $\beta$ ME was then removed by dialysis against the same buffer lacking $\beta$-ME. Then, the $\mathrm{scFv}$ was refolded by gradual removal of $\mathrm{GuHCl}$ using stepwise dialysis against Tris buffer containing $\mathrm{GuHCl}(3,2,1,0.5,0.1,0 \mathrm{M})$. At the $1 \mathrm{M}$ and $0.5 \mathrm{M}$ $\mathrm{GuHCl}$ stages, $400 \mathrm{~mm}$ L-arginine and of $600 \mu \mathrm{M}$ oxidized glutathione (GSSG) were added to facilitate the formation of disulfide bonds. After stepwise dialysis, the refolded scFv solution was centrifuged at $14000 \mathrm{rpm}$ for $20 \mathrm{~min}$ at $4{ }^{\circ} \mathrm{C}$ to remove aggregated protein and used for ELISA as a PL-scFv antibody.

Indirect Competitive ELISA Using Refolded PL-scFv The reactivity of the refolded PL-ScFv antibody was determined in the indirect competitive ELISA. A 96-well immunoplate (Nunc, Roskilde, Denmark) was coated with PLOva $(1 \mu \mathrm{g} / \mathrm{ml})$ conjugates in carbonate buffer $100 \mu \mathrm{l}(\mathrm{pH} 9)$ and incubated at $37^{\circ} \mathrm{C}$ for $1 \mathrm{~h}$. The plate was washed three times with phosphate-buffered saline containing $0.05 \%(\mathrm{v} / \mathrm{v})$ Tween 20 (TPBS) and then treated with phosphate-buffered saline $300 \mu \mathrm{l}$ containing $5 \%(\mathrm{w} / \mathrm{v})$ skimmed milk for $1 \mathrm{~h}$ to reduce non specific adsorption. PL and plant sample extracts were dissolved with methanol and diluted with $\mathrm{H}_{2} \mathrm{O}$ to give $20 \%(\mathrm{v} / \mathrm{v})$ methanol solutions. Various concentrations of PL or samples $(50 \mu \mathrm{l})$ in $20 \%(\mathrm{v} / \mathrm{v})$ methanol were incubated with $50 \mu \mathrm{l}$ of refolded PL-scFv solution $(1.4 \mu \mathrm{g} / \mathrm{ml})$ for $1 \mathrm{~h}$ to observe competition between PL and PL-scFv antibody. The plate was washed three times with TPBS, and then incubated with $100 \mu \mathrm{l}$ of a 5000-fold diluted solution of HRP-conjugated anti-T7-Tag antibody (Novagen) for $1 \mathrm{~h}$. After washing the plate three times with TPBS, $100 \mu \mathrm{l}$ of substrate solution [ $0.3 \mathrm{mg}$ of ABTS in $100 \mathrm{~mm}$ citrate buffer containing $0.003 \%$ (v/v) $\mathrm{H}_{2} \mathrm{O}_{2}$ ] was added to each well and incubated for $15 \mathrm{~min}$. Absorbance at $405 \mathrm{~nm}$ was measured with a microplate reader (Immuno Mini NJ-2300, Nalge Nunc International).

Cross-reactivities refolded PL-scFv antibody against various compounds were calculated using the method of Weiler and Zenk. ${ }^{22)}$

\section{RESULTS AND DISCUSSION}

Construction and Expression of PL-scFv Protein The $\mathrm{VH}$ and VL fragment genes were amplified by PCR using cDNA from hybridoma cell line 3A3. After cloning the amplified genes into a plasmid, clones encoding $\mathrm{VH}$ and $\mathrm{VL}$ genes were selected according to sequence alignment of the complementary-determining region (CDR) using the Kabat and Chothia numbering scheme (http://www.bioinf.org.uk/ abs). Cloned VH and VL genes were assembled together to construct a gene encoding a full-length recombinant antibody with a flexible $\left(\mathrm{Gly}_{4} \mathrm{Ser}\right)_{3}$ linker and restriction enzyme sites at both ends (BamHI and SalI) using SOE-PCR. The assembled $\mathrm{scFv}$ antibody gene was digested, cloned into the pET28a vector, and expressed in E. coli BL21 (DE3). Analysis of the nucleic acid sequence of the constructed $\mathrm{scFv}$ gene on the plasmid vector revealed that it had 717-bp nucleotides encoding 239 amino acids including the $\left(\mathrm{Gly}_{4} \mathrm{Ser}\right)_{3}$ linker as predicted (Fig. 2). This nucleotide sequences were assigned in DDBJ as accession number AB470492.

Subsequently, time-course expression was studied to optimize the time for expression of the PL-scFv protein. It was found that the expression level reached the maximum $3 \mathrm{~h}$ after IPTG induction (Fig. 3).

SDS-PAGE analysis of cellular protein extracts from $E$. coli demonstrated that $\mathrm{scFv}$ monomer was expressed as an insoluble protein with a molecular mass of $29 \mathrm{kDa}$, which agreed with the theoretical value for scFv (29539 Da) (Fig. 4).

Purification and Refolding of PL-scFv Protein Expressed PL-ScFv present as inclusion bodies in the insoluble fraction was purified using IMAC and then refolded with a dialysis method. ${ }^{21)}$ The total weight of purified protein from the inclusion bodies and refolded protein after purification was $5.6 \mathrm{mg}$ and $2.1 \mathrm{mg}$ per $100 \mathrm{ml}$ of cell culture, respectively.

Method Validation Recombinant PL-scFv was characterized in the indirect competitive ELISA using PL-Ova as a solid-phase antigen. After competition, free PL-scFv $(1.4 \mu \mathrm{g} /$ $\mathrm{ml}$ ) was bound to a polystyrene micro-immunoplate precoated with PL-Ova $(1 \mu \mathrm{g} / \mathrm{ml})$. After washing the plate, the amount of PL-scFv antibodies bound to the PL-Ova conjugate was measured using HRP-labeled secondary antibody against T7-tag, and a substrate was added to develop color. The range of PL concentration detectable in this assay was $0.2-25 \mu \mathrm{g} / \mathrm{ml}$ (Fig. 5). It became evident from this experiment that the indirect competitive ELISA using PL-scFv displayed the same sensitivity as that using MAb $3 \mathrm{~A} 3$.

To evaluate the specificity of PL-scFv, the CRs of PL-scFv antibody with other compounds were determined using the developed ELISA and the calculation described by Weiler and Zenk. Table 1 shows that the CRs of PL-scFv against menadion (2-methyl-1,4-naphthoquinone; vitamin $\mathrm{K}_{3}$ ) and juglone (5-hydroxy-1,4-naphthoquinone) were $7.7 \%$ and 7.4 $\%$, respectively, whereas other tested compounds didn't exhibit any cross-react with it $(<0.005 \%)$. It was tantalizing that these data showed that the characteristics of the $\mathrm{scFv}$ antibody against naphthoquinones were improved, although it is generally accepted that the specificity of the scFv antibody is identical (or very similar) to that of the parental antibody, especially against low molecular-weight compounds. Since the antigen in this study was hapten, MAb $3 \mathrm{~A} 3$ recognized menadion with nearly the same specificity as PL (Table 1). However, CR of MAb 3A3 against menadion was lacked in the case of PL-scFv. It is supposed that the conformational difference between the parental antibody (MAb 3A3) and $\mathrm{scFv}$ (PL-scFv) had occurred because the conformation of $\mathrm{scFv}$, which does not have constant regions, is altered and different from that of the parental antibody. As a result of the lack of CR against menadion, which was appeared to be 80.5 $\%$ in MAb 3A3, the specificity-improved scFv had been constructed. In addition, the low molecular weight (MW 188) of 




Fig. 2. Nucleotide and Deduced Amino Acid Sequences of PL-scFv

The linker fragment is shown in italics. The nucleotide sequences encoding the complementary-determining regions (CDRs) are underlined. HCDRs, CDRs in heavy chain; LCDRs, CDRs in light chain.

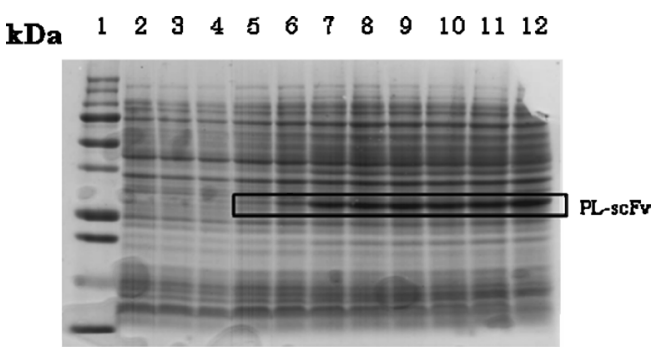

Fig. 3. Time-Course Expression of the PL-scFv Protein Induced by IPTG

Lane 1, marker proteins; lane 2, total protein before IPTG induction; lanes 3-12, total protein $15,30,45$, and $60 \mathrm{~min}$ and $2,3,4.5,6,9$, and $24 \mathrm{~h}$ after IPTG induction, respectively.

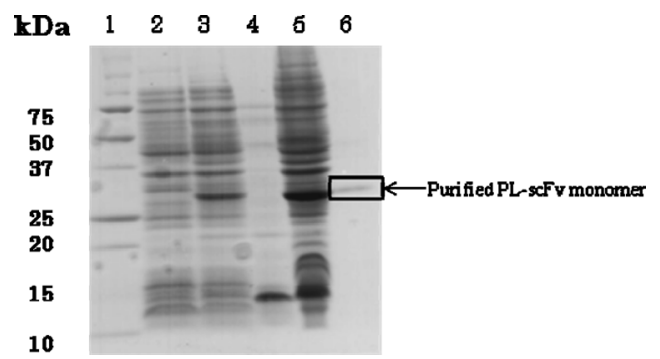

Fig. 4. SDS-PAGE Analysis of PL-scFv Monomer from E. coli BL21 (DE3) Harboring the Construct pET28a (+)

Lane 1, marker proteins; lane 2, total protein before IPTG induction; lane 3, total protein after IPTG induction; lane 4, soluble fraction after induction; lane 5, insoluble fraction after IPTG induction; lane 6, purified and refolded scFv $(0.21 \mu \mathrm{g})$.

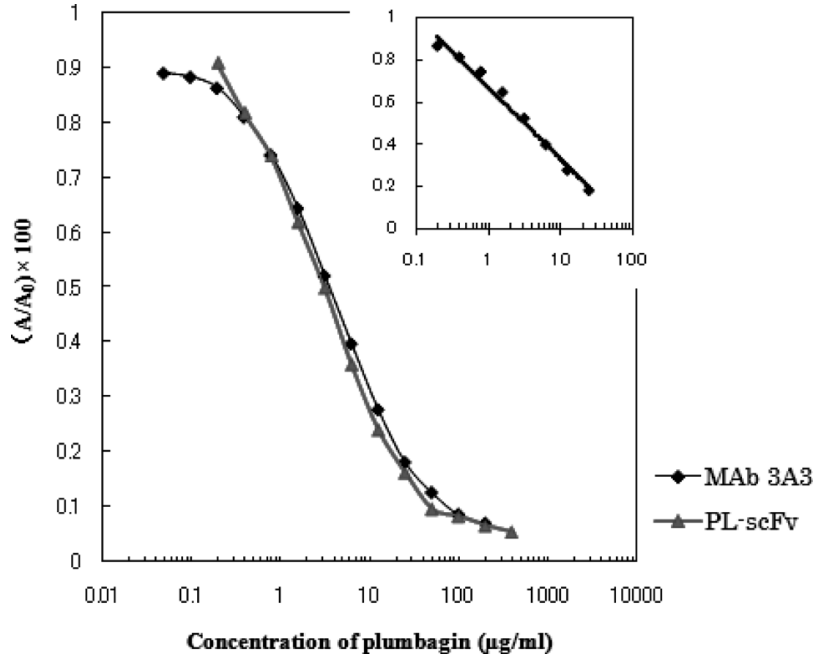

Fig. 5. Standard ELISA Curve for the Determination of Plumbagin Using Recombinant PL-scFv Protein and Its Parental Monoclonal Antibody MAb $3 \mathrm{~A} 3$

Red triangles and red curve show the standard curve using PL-scFv. Blue squares and blue curve show the case when MAb $3 \mathrm{~A} 3$ was used. Concentrations of PL-scFv and PL-Ova coating conjugate were $1.4 \mu \mathrm{g} / \mathrm{ml}$ and $1 \mu \mathrm{g} / \mathrm{ml}$, respectively. The insert shows the linearized calibration curve using the same experimental data. 
Table 1. Cross-Reactivities (CRs) of PL-svFv and MAb 3A3 against Various Compounds

\begin{tabular}{lcc}
\hline \hline & \multicolumn{2}{c}{ CRs (\%) } \\
\cline { 2 - 3 } \multicolumn{1}{c}{ Compound } & & MAb \\
& PL-scFv & $3 \mathrm{~A} 3$ \\
\hline Plumbagin (2-methyl-5-hydroxy-1,4-naphthoquinone) & 100 & 100 \\
Menadion (2-methyl-1,4-naphthoquinone) & 7.7 & 80.5 \\
Juglone (5-hydroxy-1,4-naphthoquinone) & 7.4 & $<0.005$ \\
Lawsone (2-hydroxy-1,4-naphthoquinone) & $<0.005$ & $<0.005$ \\
1,4-Naphthoquinone & $<0.005$ & $<0.005$ \\
Sennoside A & $<0.005$ & $<0.005$ \\
Sennoside B & $<0.005$ & $<0.005$ \\
1-Naphthol & $<0.005$ & $<0.005$ \\
2-Naphthol & $<0.005$ & $<0.005$ \\
Ginsenoside Re & $<0.005$ & $<0.005$ \\
Ginsenoside Rb1 & $<0.005$ & $<0.005$ \\
Glycyrrhizin & $<0.005$ & $<0.005$ \\
Solamargine & $<0.005$ & $<0.005$ \\
Naringin & $<0.005$ & $<0.005$ \\
Hesperidin & $<0.005$ & $<0.005$ \\
Rutin & $<0.005$ & $<0.005$ \\
Colchicine & $<0.005$ & $<0.005$ \\
Artemisine & $<0.005$ & $<0.005$ \\
Berberine & $<0.005$ & $<0.005$ \\
Ephedrine & $<0.005$ & $<0.005$ \\
Atropine & $<0.005$ & $<0.005$ \\
Cinnamic acid & $<0.005$ & $<0.005$ \\
Catechol & $<0.005$ & $<0.005$ \\
\hline CRswe & & \\
\hline & & \\
& & \\
& & \\
& &
\end{tabular}

CRs were calculated using the method of Weiler and $\mathrm{Zenk}^{22}$ as follows:

$$
\mathrm{CR}(\%)=\frac{\mathrm{IC}_{50} \text { for PL }}{\mathrm{IC}_{50} \text { for compound under investigation }} \times 100
$$

PL contributes to the specificity of PL-scFv compared with other previously constructed scFvs. The scFvs against bisphenol A, solamargine, and paeoniflorin display almost identical CRs to low molecular-weight compounds compared with each parental MAb. ${ }^{23-25)}$ It is assumed that the paratope of these scFvs may interact with antigens through multiple moieties in a manner similar to that of each parental antibody, even though their conformation is not completely the same as that of each parental antibody. Meanwhile, CR data of MAb 3A3 against compounds structurally related to PL indicate that its paratope interacts with the methyl group of PL and menadion, but also with other moieties, mainly because of its small size and planar structure. A slight change in the conformation of PL-scFv may evoke a multipoint interaction between PL and PL-scFv at the methyl and hydroxyl groups, improving the specificity for PL.

To validate the indirect competitive ELISA using PL-scFv, intra- and inter assay precision was evaluated by testing nine different PL concentration samples in five assays performed together on the same day and on three consecutive days, respectively. Intra- and inter-assay coefficients of variation (CV) for precision were determined based on the ratios of standard deviations (SD) and means from five assays. From the results shown in Table 2, the maximum intra assay CV was $6.4 \%$, while the maximum inter assay $\mathrm{CV}$ was $5.9 \%$. All $\mathrm{CV}$ values were less than $10 \%$, indicating that the assay may be used for sample analysis.

Correlation of PL Contents in Samples Determined by ELISA in PL-scFv or MAb 3A3 Table 3 shows the results of quantitative ELISA analysis of PL contents in the root,
Table 2. Intra- and Inter-assay Coefficients of Variation (CV) for Precision of Plumbagin Analysis in ELISA

\begin{tabular}{ccc}
\hline \hline & \multicolumn{2}{c}{$\mathrm{CV}(\%)$} \\
\cline { 2 - 3 } Plumbagin $(\mu \mathrm{g} / \mathrm{ml})$ & Intra-assay $(n=5)$ & Inter-assay $(n=3)$ \\
\hline 0.20 & 1.11 & 0.44 \\
0.39 & 2.23 & 2.43 \\
0.78 & 3.03 & 0.85 \\
1.56 & 2.75 & 3.31 \\
3.13 & 4.17 & 2.59 \\
6.25 & 3.98 & 5.90 \\
12.50 & 6.42 & 3.94 \\
25.00 & 2.14 & 5.56 \\
50.00 & 1.22 & 5.20 \\
\hline
\end{tabular}

All values represent mean \pm standard deviations (S.D.) for three plates and five replicate wells for each concentration within one plate for 3 consecutive days.

Table 3. Determination of PL in Plumbago zeylanica and Nepenthes sp. Using PL-scFv and MAb 3A3

\begin{tabular}{ccc}
\hline \hline & \multicolumn{2}{c}{ Concentration (\% w/w, dry wt.) } \\
\cline { 2 - 3 } Sample & PL-scFv & MAb 3A3 \\
\hline (P. zeylanica) & & \\
Root & $0.046 \pm 0.004$ & $0.043 \pm 0.005$ \\
Stem & $0.028 \pm 0.002$ & $0.027 \pm 0.004$ \\
Leaf & $0.025 \pm 0.009$ & $0.023 \pm 0.010$ \\
Hairy root & $0.018 \pm 0.009$ & $0.014 \pm 0.006$ \\
(Nepenthes sp.) & & \\
Flower male & $0.129 \pm 0.004$ & $0.120 \pm 0.010$ \\
Flower female & $0.094 \pm 0.003$ & $0.094 \pm 0.007$ \\
Stem male & $0.047 \pm 0.003$ & $0.043 \pm 0.005$ \\
Stem female & $0.049 \pm 0.005$ & $0.047 \pm 0.002$ \\
\hline
\end{tabular}

leaf, stem, and hairy root of $P$. zeylanica, and the flowers and stems of Nepenthes sp., which were reported to contain PL. ${ }^{26)}$ These quantitative analyses of PL using PL-scFv were compared with those obtained in ELISA using MAb 3A3. The results showed that the flower part of Nepenthes sp. contained the highest amount of PL among all samples tested. In addition, the PL concentration analyzed using the two methods showed a good correlation, with a coefficient of determination $\left(r^{2}\right)$ of 0.996 . These data indicate that PL-scFv could be used as an alternative analysis of PL in plant samples.

In conclusion, successful construction, expression, purification, and refolding of a functional $\mathrm{scFv}$ antibody against PL were achieved. To the best of our knowledge, this was the first achievement regarding scFv against bioactive 1,4-naphthoquinone derivatives and it is an extremely rare case that the specificity of $\mathrm{scFv}$ was improved compared with that of parental antibody. Indirect competitive ELISA for the determination of PL using specificity-improved PL-scFv affirmed its reliability and utility in surveying low concentrations of PL in a detailed evaluation. Due to the potent pharmacologic activity of PL, it is necessary to monitor its concentration in body fluids precisely from the viewpoint of optimum usage and avoidance of side effects. Since the developed ELISA has sufficient sensitivity and accuracy to detect small amounts of PL in such samples, it may find clinical applications. In addition, our experimental data imply that the specific binding of a recombinant antibody can be improved using a facile procedure. 
Acknowledgements This work was funded by the Sasagawa Scientific Research Grant from the Japan Science Society; and the Research Fund of Kyushu University Foundation. The research in this paper was also supported in part by a Grant in Aid from the Japan Society for the Promotion of Science Asian CORE Program, the Ministry of Education, Culture, Sports, Science and Technology of Japan, and the National Center for Genetic and Biotechnology (BIOTEC), Thailand.

\section{REFERENCES}

1) Kim S. H., Kang I. C., Yoon T. J., Park Y. M., Kang K. S., Song G. Y., Ahn B. Z., Cancer Lett., 172, 171-175 (2001).

2) Sekine T., Masymizu T., Maitani T., Nagai Y., Int. J. Pharmacol., 174 133-139 (1998)

3) Plyta Z. F., Li T., Papageorgiou V. P., Mellidis A. S., Assimopoulou A. N., Pitsinos E. N., Couladouros E. A., Bioorg. Med. Chem. Lett., 8, 3385-3390 (1998).

4) Abdul K. M., Ramchender R. P., Immunopharmacology, 30, 231-236 (1995).

5) Ko F. N., Lee Y. S., Kuo S. C., Chang Y. S., Teng C. M., Biochem. Biophys. Acta, 1268, 329-334 (1995).

6) Min B. S., Miyashiro H., Hattori M., Phytother. Res., 16, S57—S62 (2002)

7) Lin L. C., Yang L. L., Chou C. J., Phytochemistry, 62, 619-622 (2003).

8) Curreli N., Sollai F., Massa L., Comandini O., Rufo A., Sanjust E., Ri naldi A., Rinaldi A. C., J. Basic Microb., 41, 253-259 (2001).

9) Likhitwitayawuid K., Kaewamatawong R., Ruangrungsi N., Krungkrai J., Planta Med., 64, 237-241 (1998).
10) Medentsev A. G., Akimenko V. K., Phytochemistry, 47, 935-959 (1998).

11) Wang Y. C., Huang T. L., J. Chromatogr. A, 1094, 99-104 (2005).

12) Hsu Y. L., Cho C. Y., Kuo P. L., Huang Y. T., Lin C. C., J. Pharmacol. Exp. Ther, 318, 484- 494 (2006).

13) Sandur S. K., Ichikawa H., Sethi G., Ahn K. S., Aggarwal B. B., J. Biol. Chem., 281, 17023-17033 (2006).

14) Sakamoto S., Putalun W., Tsuchihashi R., Morimoto S., Kinjo J., Tanaka H., Anal. Chim. Acta, 607, 100-105 (2008).

15) Kortt A. A., Dolezal Q., Power B. E., Hudson P. J., Biomol. Eng., 18, 95-108 (2001).

16) Penichet M. L., Morrison S. L., J. Immunol. Methods, 248, 91-101 (2001).

17) Adams G. P., Shaller C. C., Chappell L. L., Wu C., Horak E. M., Simmons H. H., Litwin S., Marks J. D., Weiner L. M., Brechbiel M. W., Nucl. Med. Biol., 27, 339-346 (2000).

18) Sambrook J., Russell D. W., "Molecular Cloning," 3rd ed., Cold Spring Harbor, New York, 2001.

19) Krebber A., Bornhauser S., Burmester J., Honegger A., Bosshard H. R., Pluckthun A., J. Immunol. Methods, 201, 35-55 (1997).

20) Laemmli U. K., Nature (London), 227, 680-685 (1970).

21) Umetsu M., Tsumoto K., Hara M., Ashish K., Goda S., Adschiri T., Kumagai I., J. Biol. Chem., 278, 8979-8987 (2003).

22) Weiler E., Zenk M. H., Phytochemistry, 15, 1537-1545 (1976).

23) Nishi K., Takai M., Morimune K., Ohkawa H., Biosci. Biotechnol. Biochem., 67, 1358-1367 (2003).

24) Lu Z., Masaki T., Shoyama Y., Tanaka H., Planta Med., 72, 151-155 (2006).

25) Putalun W., Taura F., Qing W., Matsushita H., Tanaka H., Shoyama Y., Plant Cell Rep., 22, 344-349 (2003).

26) Schlauer J., Nerz J., Rischer H., Acta Bot. Gallica, 152, 187-195 (2005). 